\title{
Analysis of Zinc and Copper Serum Levels in Premature Hair Graying at Young Age
}

\author{
Dwi Rita Anggraini $^{1 *} \mathbb{D}$, Lita Feriyawati ${ }^{1} \mathbb{D}$, Mega Sari Sitorus ${ }^{1}$ (D), Tri Widyawati ${ }^{2} \mathbb{D}$, Siti Syarifah $^{2}$ (D) \\ ${ }^{1}$ Department of Anatomy, Faculty of Medicine, Universitas Sumatera Utara, Medan, Indonesia; ${ }^{2}$ Department of Pharmacology \\ and Therapeutics, Faculty of Medicine, Universitas Sumatera Utara, Medan, Indonesia
}

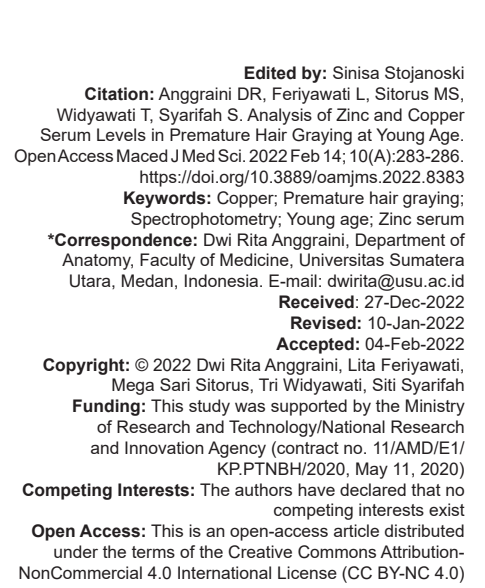

Introduction

Healthy hair is one of signs of general well health and young age. Hair is a part of esthetics tools. In fact, in Indonesia, hair is a woman's crown. Hair color and style may describe a person's physical appearance and can influence his body performance. Premature hair gray (PHG) has a bad impact to a person, reducing selfconfidence because of gray hair signifies of aging [1].

Physiologically, gray hair is associated with a loss of pigment-producing cells progressively [2]. Premature hair graying occurs before the time should be, in Caucasians before the age of 20 and 25 in Asians, and 30 in Africans [3]. The normal hair function associated with adequate and balanced nutritional intake. Lack of essential elements such as zinc, selenium, copper, iron, and multivitamins lead to pigmentary changes and hair loss. Vitamin D3 and calcium are also suspected to be related to premature hair graying since it is occurred in osteopenia [4].

To maintain normal growth and biological activities, it is required sufficient inorganic elements such as iron, zinc, selenium, and copper. Production of keratin, the essential hair structure is correlated with zinc. Zinc inhibits the hair follicle regression and accelerates hair follicle recovery [5]. Selenium is an essential trace element that acts as a cell membrane protector against lipid peroxidation and hair follicle formation [6].

Copper maintains normal hair color by activating the tyrosinase enzyme. It influences the production of crosslinks in elastin and collagen fibers in the dermis, post-translational formation of di-sulfide bonds between cysteine molecules in cytoskeletal proteins of cortical and cuticle proteins [4].

The previous study indicated lower serum levels of calcium, iron, and copper in graying hair versus control groups. The association of graying severity between serum iron and calcium levels was significantly different ( $p=0.021$ and 0.002 , respectively) but not with serum copper $(p=0.743)$ [7]. Ashraf et al. explained that there is no significant correlation between ferrum and cuprum serum trace elements with premature canities $(p>0.05)$, but otherwise between zinc serum and premature canities $(p<0.05)[8]$.

This present study was to measure zinc and copper serum levels in PHG and its correlation with the hair graying severity in college student at Universitas Sumatera Utara (USU). 


\section{Materials and Methods}

This study was a cross-sectional design with 80 samples of the college students at the USU area such as Faculty of Medicine, Dentistry, Engineering, Public Health, Mathematics and Natural Science, Agriculture, and Politeknik Negeri Medan. The protocol of this study has been approved by Medical Ethics Committee USU, No.626/KEP/USU/2020.

\section{Study subjects}

Forty respondents with PHG were included and 40 healthy controls with normal hair. The inclusion criteria were male sex, below 25 years old, having gray hair and not have skin pigmentation disorders. Written informed consent was taken from all respondents. The questionnaires including onset, location, and numbers of graying hair were collected. According to the total number of graying, the canities were categorized into mild (<10 gray hair); moderate (10-100 gray hair); and severe (>100 gray hair) [9]. The serum zinc and copper were measured by atomic absorption spectrophotometry Perkin Elmer Zeeman 5100 PC. The data were analyzed with Chi-squared and MannWhitney U-tests, $p<0.05$ was considered significant.

\section{Results}

The mean age of cases was $20.28 \pm 1.99$ (mean vs. standard deviation), range was 19-24 years old and the control was $21.25 \pm 2.02$, range was $18-24$ years old.

The zinc serum concentration was significantly lower in PHG compared with controls $(0.48 \pm 0.19$ vs. $1.92 \pm 0.68 \mathrm{ug} / \mathrm{dL}, \mathrm{p}=0.001)$, while copper serum concentration was not significantly lower in $P H G$ compared with controls $(0.08 \pm 0.03$ vs. $0.09 \pm 0.18 \mathrm{ug} / \mathrm{dL}$, $p=0.706)$ (Table 1 and Figure 1).

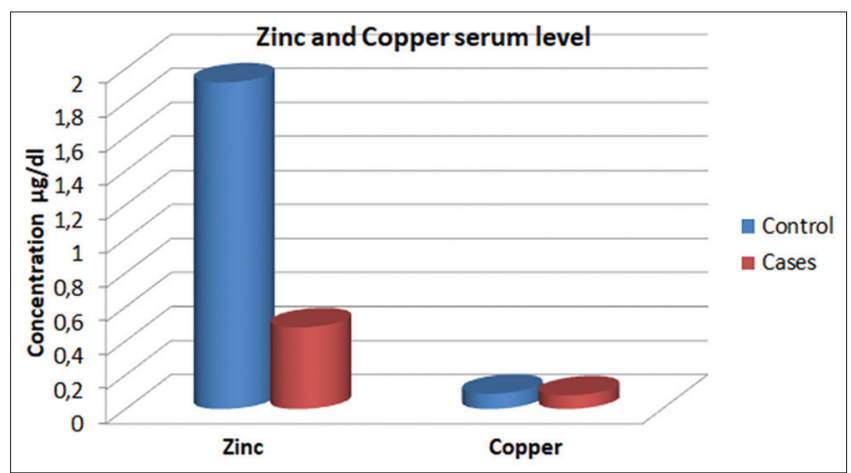

Figure 1: Trace elements levels in control and cases

In this study, majority of the gray areas were located at parietal region (50\%), followed by more than one region, frontal, occipital, and temporal regions were $17 \%, 15 \%, 13 \%$, and $5 \%$, respectively (Figure 2 ).

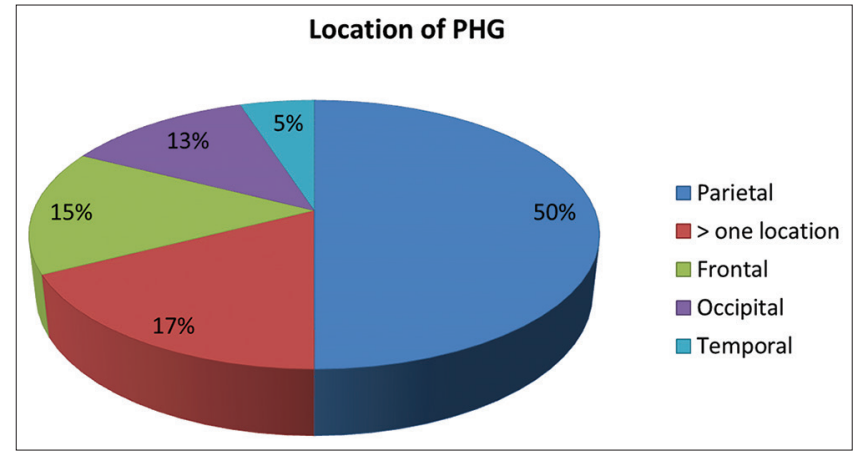

Figure 2: Distribution location of premature hair gray

This study showed zinc and copper serum levels not significantly correlated the severity of hair graying $(p>0.05)$.

\section{Discussion}

The hair pigmentation is one of the most unique traits in humans ranging from black, brown, and blonde to red. Natural human hair color is determined by the melanin pigment produced by melanocytes which is a derivative of the neural crest. Human hair pigments contain two types of melanin as follows: Eumelanin and pheomelanin [1].

The certain etiopathogenesis of gray hair remains unclear. Multiple factors are involved in hair graying. Chakrabarty et al. (proposed that graying is caused by the depletion of hair follicle bulbar melanocytes, due to dysregulation of antioxidant mechanisms and expression of anti-apoptotic factors. Few studies have also showed that many factors, such as genetic defects, inflammatory, environmental, and habitual factors (cigarette smoking, chemical and drug consumption, and psychoemotional stress), may trigger oxidative stress and induce graying. Hair graying may also reflect nutritional deficiencies (especially of vitamins and trace elements) [10], [11], [12], [13].

This study was a continuation of the previous studies to find out the risk factors which are associated with premature graying, including family history, Vitamin D level, calcium, Vitamin B12, Fe, and trace elements. The mean age of cases was $20.28 \pm 1.99$ (mean vs. standard deviation), range was 19-24 years old and the control was $21.25 \pm 2.02$, range was $18-24$ years old.

The distribution pattern of gray hair in males more commonly located at the temporal and occipital regions. Second, graying usually starts in temporal areas in males, contrast to females in the frontal area. In this study, an analysis of questionnaire responses 
Table 1: The correlation of zinc and copper serum levels with severity of PHG

\begin{tabular}{lllll}
\hline $\begin{array}{l}\text { Serum } \\
\text { concentration (ug/dl) }\end{array}$ & \multicolumn{2}{l}{ Severity of hair graying } & $\mathrm{p}$ \\
\cline { 2 - 4 } & Mild $(\mathrm{n}=14)$ & Moderate $(\mathrm{n}=16)$ & Severe $(\mathrm{n}=10)$ & \\
\hline Zinc & $0.48 \pm 0.19$ & $0.50 \pm 0.13$ & $0.35 \pm 0.20$ & $\mathrm{p}=0.08$ \\
Copper & $0.09 \pm 0.03$ & $0.07 \pm 0.03$ & $0.10 \pm 0.03$ & $\mathrm{p}=0.11$ \\
\hline PHG: Premature hair gray. & & & &
\end{tabular}

revealed that the majority of the gray areas were in parietal region (50\%), followed the other areas. Jo et al. revealed that the temporal area was significantly more involved in men, whereas the frontal and parietal areas were involved in women [14]. Daulatabad et al. showed involvement of the frontal more likely than temporal region. Another study had reported that differences in pattern related with racial variation [15].

In this study, zinc serum concentration was significantly lower in PHG compared to controls $(0.48 \pm 0.19$ vs. $1.92 \pm 0.68 \mathrm{ug} / \mathrm{dL}, p=0.001)$ while copper serum concentration was not significantly lower in PHG compared to controls $(0.08 \pm 0.03$ vs. $0.09 \pm 0.18 \mathrm{ug} / \mathrm{dL}$, $\mathrm{p}=0.706$ ). This was line with Ashraf et al. in 31 case subjects and 31 controls showed a significant correlation between $\mathrm{Zn}$ serum and premature canities $(p<0.05)$, there was no significant correlation between $\mathrm{Fe}$ and $\mathrm{Cu}$ serum with premature canities $(p>0.05)$. There was a significant difference between $\mathrm{Zn}$ and $\mathrm{Cu}$ serum levels of the premature canities group compared to controls group $(p<0.05)$, there was no significant difference between Fe serum premature canities group compared to controls group $(p<0.05)$ [8]. The results in this study were different from a study conducted by Fatemi et al. assessed the association between $\mathrm{Fe}, \mathrm{Zn}$, and $\mathrm{Cu}$ serum concentrations with premature canities, where the mean level of $\mathrm{Fe}$ serum was significantly higher in the case group than in the control group [10].

The process of hair graying is usually progressive and permanent, includes decreasing in melanogenesis enzymes, alteration of DNA repair, and loss of antioxidant mechanisms. Premature graying is a result of oxidative damage in follicle melanocytes, depletion of antioxidant enzymes, and hydroxyl radical scavenger activities [16].

Recent study reported that smoking, obesity, family history, environmental, and nutritional deficiencies were considered to be associated with PHG in young men [9], [17]. Many studies have reported premature graying hair correlate with trace elements deficiencies. Iron and Vitamin B12 affected pigmentation and hair growth [18], whereas deficiency of Vitamin D related to hair graying [19]. Trace elements deficit may lead to hypopigmentation, such as copper ion required to activate tyrosinase enzyme to maintain normal color in melanocytes [16].

This study supported a critical role of trace elements as risk factors of $\mathrm{PHG}$ at young age especially in college students at USU, Medan. Attempts to slow down PHG with intake of micronutrients were needed to investigate furthermore.

\section{Conclusion}

Decreasing of zinc and copper serum concentrations may contribute to risk of premature hair graying of college student at USU.

\section{References}

1. Kumar AB, Shamim H, Nagaraju U. Premature graying of hair: Review with updates. Int J Trichol. 2018;10(5):198-203. https:// doi.org/10.4103/ijt.ijt_47_18

PMid:30607038

2. Trüeb RM. Pharmacological interventions in aging hair Clin Interv Aging. 2006;1:121-9. https://doi.org/10.2147/ ciia.2006.1.2.121

PMid:18044109

3. Sehrawat M, Sinha S, Meena N, Sharma PK. Biology of hair pigmentation and its role in premature canities. Pig Int. 2017;4(1):7-12. https://doi.org/10.4103/2349-5847.208297

4. Galbraith $\mathrm{H}$. Fundamental hair follicle biology and fine fibre production in animals. 2014;4(9):1490-509. https://doi. org/10.1017/S175173111000025X

PMid:22444696

5. Kil MS, Kim CW, Kim SS. Analysis of serum zinc and copper concentrations in hair loss. Ann Dermatol. 2013;25(4):405-9. https://doi.org/10.5021/ad.2013.25.4.405

PMid:24371385

6. Tinggi U. Selenium: Its role as antioxidant in human health Environt Health Prev Med. 2008;13(2):102-8. https://doi. org/10.1007/s12199-007-0019-4

PMid:19568888

7. El-Sheikh AM, Elfar NN, Mourad HA, Hewedy ES. Relationship between trace elements and premature hair graying. Int $J$ Trichol. 2018;10(6):278-83. https://doi.org/10.4103/ijt.ijt_8_18 PMid:30783336

8. Ashraf $P$, Simanungkalit $R$, Jusuf N. Association between the Levels of Ferrum, Zinc and Copper Serum and Premature Canities. In: Proceedings of the $23^{\text {rd }}$ Regional Conference of Dermatology (RCD); 2018. p. 122-6.

9. Shin $\mathrm{H}$, Ryu HH, Yoon J, Jo S, Jang S, Choi M, et al. Association of premature hair graying with family history, smoking, and obesity: A cross-sectional study. J Am Acad Dermatol. 2015;72(2):321-7. https://doi.org/10.1016/j.jaad.2014.11.008 PMid:25484268

10. Naieni FF, Ebrahimi B, Vakilian HR, Shahmoradi Z Serum iron, zinc, and copper concentration in premature graying of hair. Biol Trace Elem Res. 2012;146:30-4. https://doi. org/10.1007/s12011-011-9223-6

PMid:21979243

11. Chakrabarty S, Krishnappa PG, Gowda DG, Hiremath J. Factors associated with premature hair graying in a young Indian population. Int J Trichol. 2016;8(1):11-4. https://doi. org/10.4103/0974-7753.179384

PMid:27127369

12. Bhat RM, Sharma R, Pinto AC, Dandekeri S, Martis J. Epidemiological and investigative study of premature graying of hair in higher secondary and pre-university school children. Int J Trichol. 2013;5(1):17-21. https://doi.org/10.4103/0974-7753.114706 PMid:23960391 
13. Jo SK, Lee JY, Lee $\mathrm{Y}$, Kim CD, Lee JH, Lee YH. Three streams for the mechanism of hair graying. Ann Dermatol. 2018;30(4):397-401. https://doi.org/10.5021/ad.2018.30.4.397 PMid:30065578

14. Jo SJ, Paik SH, Cho JW, Lee JH, Cho S, Kim KH, et al. Hair graying pattern depends on gender, onset age and smoking. Acta Derm Venereol. 2012;92(2):160-1. https://doi. org/10.2340/00015555-1181 PMid:22113716

15. Daulatabad D, Singal A, Grover C, Chhillar N. Profile of Indian patients with premature canities Indian J Dermatol Venereol Leprol. 2016;82(2):169-72. https://doi. org/10.4103/0378-6323.168911 PMid:26585843

16. Shi Y, Luo LF, Liu XM, Zhou Q, Xu SZ, Lei TC. Premature graying as a consequence of compromised antioxidant activity in hair bulb melanocytes and their precursors. PLoS One. 2014;9(4):e93589.

PMid:24695442

17. Bhat YJ, Hassan I, Sajad P, Malik R, Majid S, Mubashir S, et al. Serum iron, ferritin and calcium levels in premature canities. Hair Ther Transplant. 2013;6:142. https://doi. org/10.4172/2167-0951.1000142

18. Krugluger W, Stiefsohn K, Laciak K. Vit B 12 activates wnt pathway in human hair follicle by induction of $b$ catenin and inhibition of glycogen synthase kinase 3 transcription. J Cosmet Dermatol Sci Appl. 2011;1:25-9. https://doi.org/10.4236/ jcdsa.2011.12004

19. Anggraini DR, Feriyawati L, Hidayat. Serum ferritin and Vitamin $D$ levels in premature hair graying of college student at the Universitas Sumatera Utara area. IOP Conf Ser Earth Environ Sci. 2019;305:1-5. 